\title{
Hypocholesterolaemia and non-cardiovascular disease: metabolic studies on subjects with low plasma cholesterol concentrations
}

\author{
C B MARENAH, B LEWIS, D HASSALL, A LA VILLE, C CORTESE, W D MITCHELL, \\ K R BRUCKDORFER, B SLAVIN, N E MILLER, P R TURNER, E HEDUAN
}

\begin{abstract}
Some epidemiological studies have suggested an inverse relation between serum cholesterol concentration and mortality from cancer. Two hypotheses that might explain such a relation were investigated. To assay potentially deleterious effects of hypocholesterolaemia on cell membranes the lipid content and fluidity of blood mononuclear cells were measured in healthy male volunteers with a wide range of serum cholesterol concentration (3.2-10.0 $\mathrm{mmol} / 1$ (124-387 $\mathrm{mg} / 100 \mathrm{ml})$ ). Fluidity, unesterified cholesterol content, and the ratio of cholesterol to phospholipid were unrelated to serum cholesterol and to low density lipoprotein cholesterol concentrations. Similar measurements were made on fibroblasts and mononuclear cells incubated with a range of concentrations of low density lipoprotein; fluidity was altered only at extremely low concentrations, suggesting that changes in cell membranes are unlikely to occur at serum cholesterol concentrations attainable by dietary or drug treatment of hyperlipidaemia.
\end{abstract}

\footnotetext{
Department of Chemical Pathology and Metabolic Disorders, St Thomas's Hospital, London SE1 7EH

C B MARENAH, PHD, MRCP, lecturer

B LEWIS, MD, FRCP, professor

A LA VILLE, AIMLS, medical laboratory scientific officer C CORTESE, MD, lecturer

W D MITCHELL, PHD, MRCPATH, top grade biochemist

B SLAVIN, MB, MRCPATH, senior lecturer

N E MILLER, MD, MRCPATH, reader

P R TURNER, BSC, medical laboratory scientific officer

E HEDUAN, BSC, basic grade biochemist

Department of Biochemistry and Chemistry, Royal Free Hospital School of Medicine, London WC1

D HASSALL, BSC, postgraduate research student

K R BRUCKDORFER, BSC, PHD, senior lecturer in biochemistry

Correspondence to: Dr C B Marenah.
}

In the same population direct relations were confirmed between low density lipoprotein concentration and plasma concentrations of retinol and $\beta$ carotene. This is compatible with the suggestion that an association between low cholesterol concentration and cancer may be secondary to a relation between low retinoid concentrations and cancer.

\section{Introduction}

The risk of coronary heart disease is minimal in people with plasma cholesterol concentrations below $5.2 \mathrm{mmol} / 1(201 \mathrm{mg}$ / $100 \mathrm{ml}){ }^{1} \mathrm{~A}$ committee of the World Health Organisation proposed this value as an upper limit of normality, ${ }^{1}$ and an optimal population mean of $4.5 \mathrm{mmol} / 1(174 \mathrm{mg} / 100 \mathrm{ml})$ has been suggested. ${ }^{2}$ The possibility of untoward effects of such concentrations deserves careful consideration. Of 27 longitudinal epidemiological studies that have addressed this question, 15 detected an excess mortality from malignant neoplasms in men but not women with plasma cholesterol concentrations in the lowest quintile. $^{3}$ In one trial of the hypolipidaemic drug clofibrate an increased mortality from non-cardiovascular disease was observed $^{4}$ including a non-significant excess of deaths from cancer; this was not evident in another large trial of clofibrate.

These two lines of evidence led to the hypothesis ${ }^{6}$ that prolonged contact of cells with hypocholesterolaemic plasma or tissue fluid may have deleterious effects on plasma membrane fluidity, implying that hypocholesterolaemia is causally related to the risk of malignancy. Inbar and Shinitzky reported that malignant behaviour in lymphoma cells was related to their low content of unesterified cholesterol, ${ }^{7}$ but a later report did not confirm this. ${ }^{8}$ An alternative hypothesis, that the hypocholesterolaemia results from undetected cancer, receives support from studies in which the excess of deaths from cancer was found only in a relatively short period after the detection of low serum cholesterol concentrations. ${ }^{910}$

Plasma retinol concentrations ${ }^{11}$ and dietary intake of $\beta$ carotene $^{12}$ are inversely related to mortality from cancer, and a 
positive relation has been observed between plasma concentrations of cholesterol and retinol. ${ }^{13}$ Hence a third hypothesis is that the inconsistent but often observed relation between cancer and plasma cholesterol concentration is merely secondary to this association between retinol and cholesterol.

In this study we investigated the mechanisms underlying the first and third of these hypotheses in a normal adult population with a wide range of serum cholesterol concentrations. We examined plasma membrane fluidity and cellular unesterified lasmas or was taking any drugs known to affect lipid metabolism. Subjects taking therapeutic diets, those with a weight change in excess of $1.5 \mathrm{~kg}$ in the preceding two months, and those with intercurrent illnesses were excluded. A second blood sample was obtained from the recalled subjects in the fasted state.

Lipoprotein fractionation was performed by preparative ultracentrifugation at density $1.006 \mathrm{~g} / \mathrm{ml}$ for very low density lipoprotein and by heparin manganese chloride precipitation for high density lipoprotein. Cholesterol concentrations were measured enzymatically (Boehringer Mannheim catalogue No 187313). Low density lipo-

TABLE I-Ratio of unesterified cholesterol to phospholipid and relative microviscosity in mononuclear cells, by quintile of serum cholesterol concentrations and lipoprotein cholesterol concentrations

\begin{tabular}{|c|c|c|c|c|c|}
\hline & I & II & III & IV & $\mathbf{V}$ \\
\hline & \multicolumn{5}{|c|}{ Serum cholesterol } \\
\hline Range (mmol/1) & $3 \cdot 20-4 \cdot 90$ & $4 \cdot 94-5 \cdot 62$ & $5 \cdot 65-6 \cdot 40$ & $6 \cdot 44-7 \cdot 39$ & $7 \cdot 45-9 \cdot 80$ \\
\hline Mean \pm SD $(\mathrm{mmol} / \mathrm{l})$ & $4.43 \pm 0.37$ & $5 \cdot 25 \pm 0 \cdot 22$ & $6.05 \pm 0.25$ & $6 \cdot 86 \pm 0 \cdot 28$ & $8 \cdot 22 \pm 0.63$ \\
\hline \multirow[t]{2}{*}{$\begin{array}{l}\text { phospholipid molar ratio } \\
\text { Relative microviscosity }\end{array}$} & $\begin{array}{l}0.46 \pm 0.30 \\
0.90 \pm 0.05\end{array}$ & $\begin{array}{l}0.52 \pm 0.28 \\
0.89 \pm 0.05\end{array}$ & $\begin{array}{l}0.52 \pm 0.38 \\
0.90 \pm 0.05\end{array}$ & $\begin{array}{l}0.61 \pm 0.40 \\
0.89 \pm 0.04\end{array}$ & $\begin{array}{l}0.57 \pm 0.32 \\
0.90 \pm 0.04\end{array}$ \\
\hline & \multicolumn{5}{|c|}{ Very low density lipoprotein cholesterol } \\
\hline Range (mmol/l) & $0 \cdot 01-0 \cdot 18$ & $0 \cdot 19-0 \cdot 30$ & $0.32-0.52$ & $0.55-0.77$ & $0 \cdot 79-2 \cdot 78$ \\
\hline Mean \pm SD $(\mathrm{mmol} / \mathrm{l})$ & $0 \cdot 10 \pm 0 \cdot 05$ & $0 \cdot 25 \pm 0.04$ & $0.42 \pm 0.07$ & $0.66 \pm 0.07$ & $1 \cdot 21 \pm 0 \cdot 47$ \\
\hline \multirow[t]{2}{*}{$\begin{array}{l}\text { phospholipid molar ratio } \\
\text { Relative microviscosity }\end{array}$} & $\begin{array}{l}0.47 \pm 0.35 \\
0.91 \pm 0.05\end{array}$ & $\begin{array}{l}0.44 \pm 0.33 \\
0.90 \pm 0.04\end{array}$ & $\begin{array}{l}0.54 \pm 0.28 \\
0.90 \pm 0.04\end{array}$ & $\begin{array}{l}0.64 \pm 0.37 \\
0.89 \pm 0.04\end{array}$ & $\begin{array}{l}0.68 \pm 0.35 \\
0.88 \pm 0.04\end{array}$ \\
\hline & \multicolumn{5}{|c|}{ Low density lipoprotein cholesterol } \\
\hline Range (mmol/1) & $1 \cdot 45-3.06$ & $3 \cdot 11-3 \cdot 60$ & $3 \cdot 64-4 \cdot 11$ & $4 \cdot 16-5 \cdot 01$ & $5 \cdot 05-7 \cdot 55$ \\
\hline $\begin{array}{l}\text { Mean } \pm \mathrm{SD}(\mathrm{mmol} / \mathrm{l}) \\
\text { Cholesterol: }\end{array}$ & $2 \cdot 49 \pm 0 \cdot 48$ & $3 \cdot 36 \pm 0 \cdot 16$ & $3 \cdot 89 \pm 0 \cdot 16$ & $4 \cdot 60 \pm 0 \cdot 26$ & $5 \cdot 92 \pm 0.71$ \\
\hline \multirow[t]{2}{*}{$\begin{array}{l}\text { phospholipid molar ratio } \\
\text { Relative microviscosity }\end{array}$} & $\begin{array}{l}0.58 \pm 0.32 \\
0.88 \pm 0.04\end{array}$ & $\begin{array}{l}0.49 \pm 0.27 \\
0.90 \pm 0.04\end{array}$ & $\begin{array}{l}0.53 \pm 0.42 \\
0.88 \pm 0.05\end{array}$ & $\begin{array}{l}0.68 \pm 0.40 \\
0.91 \pm 0.04\end{array}$ & $\begin{array}{l}0.50 \pm 0.28 \\
0.89 \pm 0.04\end{array}$ \\
\hline & \multicolumn{5}{|c|}{ High density lipoprotein cholesterol } \\
\hline Range (mmol/1) & $0 \cdot 87-1 \cdot 33$ & $1 \cdot 34-1 \cdot 47$ & $1 \cdot 48-1.66$ & $1 \cdot 67-1 \cdot 79$ & $1 \cdot 80-2 \cdot 55$ \\
\hline $\begin{array}{l}\text { Mean } \pm \text { SD }(\mathrm{mmol} / \mathrm{l}) \\
\text { Cholesterol: }\end{array}$ & $1 \cdot 18 \pm 0 \cdot 13$ & $1.40 \pm 0.04$ & $1.59 \pm 0.05$ & $1 \cdot 72 \pm 0 \cdot 04$ & $1 \cdot 99 \pm 0 \cdot 18$ \\
\hline $\begin{array}{l}\text { phospholipid molar ratio } \\
\text { Relative microviscosity }\end{array}$ & $\begin{array}{l}0.57 \pm 0.35 \\
0.91 \pm 0.05\end{array}$ & $\begin{array}{l}0.50 \pm 0.33 \\
0.88 \pm 0.04\end{array}$ & $\begin{array}{l}0.53 \pm 0.43 \\
0.91 \pm 0.04\end{array}$ & $\begin{array}{l}0.60 \pm 0.25 \\
0.92 \pm 0.05\end{array}$ & $\begin{array}{l}0.50 \pm 0.36 \\
0.89 \pm 0.04\end{array}$ \\
\hline
\end{tabular}

Conversion: SI to traditional units-Cholesterol: $1 \mathrm{mmol} / 1 \approx 38.7 \mathrm{mg} / 100 \mathrm{ml}$

TABLE II-Serum retinoid concentrations, by quintile of plasma cholesterol concentration and lipoproteins

\begin{tabular}{|c|c|c|c|c|c|}
\hline & I & II & III & IV & $\mathbf{V}$ \\
\hline & \multicolumn{5}{|c|}{ Cholesterol } \\
\hline Range (mmol/1) & $3 \cdot 20-4 \cdot 90$ & $4 \cdot 94-5 \cdot 62$ & $5 \cdot 65-6 \cdot 40$ & $6 \cdot 44-7 \cdot 39$ & $7 \cdot 45-9 \cdot 80$ \\
\hline \multirow[t]{2}{*}{$\begin{array}{l}\beta \text { carotene }(\mathrm{nmol} / \mathrm{l}) \\
\text { Retinol }(\mu \mathrm{mol} / \mathrm{l}) \\
\text { Retinol: retinol binding protein molar ratio }\end{array}$} & $\begin{array}{l}685 \pm 330 \\
2 \cdot 1 \pm 0 \cdot 6 \\
0 \cdot 74 \pm 0 \cdot 13\end{array}$ & $\begin{aligned} & 806 \pm 423 \\
& 2 \cdot 4 \pm 0.5^{*} \\
& 0 \cdot 76 \pm 0.07\end{aligned}$ & $\begin{aligned} 799 & \pm 328 \\
2 \cdot 6 & \pm 0 \cdot 6^{* *} \\
0 \cdot 78 & \pm 0 \cdot 12\end{aligned}$ & $\begin{array}{c}1088 \pm 518^{* * *} \\
2 \cdot 6 \pm 0 \cdot 5^{* * *} \\
0 \cdot 79 \pm 0 \cdot 12\end{array}$ & $\begin{array}{l}941 \pm 518^{*} \\
2 \cdot 7 \pm 0 \cdot 9^{* *} \\
0 \cdot 77 \pm 0.11\end{array}$ \\
\hline & \multicolumn{5}{|c|}{ Very low density lipoprotein cholesterol } \\
\hline Range ( $\mathrm{mmol} / \mathrm{l})$ & $0 \cdot 01-0 \cdot 18$ & $0 \cdot 19-0 \cdot 30$ & $0 \cdot 32-0 \cdot 52$ & $0.55-0.77$ & $0 \cdot 79-2 \cdot 78$ \\
\hline \multirow[t]{2}{*}{$\begin{array}{l}\beta \text { carotene }(\mathrm{nmol} / \mathrm{l}) \\
\text { Retinol }(\mu \mathrm{mol} / \mathrm{l}) \\
\text { Retinol : retinol binding protein molar ratio }\end{array}$} & $\begin{array}{c}922 \pm 445 \\
2 \cdot 2 \pm 0 \cdot 6 \\
0 \cdot 75 \pm 0 \cdot 11\end{array}$ & $\begin{array}{c}833 \pm 492 \\
2 \cdot 4 \pm 0 \cdot 6 \\
0 \cdot 76 \pm 0 \cdot 11\end{array}$ & $\begin{array}{l}950 \pm 482 \\
2 \cdot 6 \pm 0 \cdot 6^{* *} \\
0 \cdot 77 \pm 0 \cdot 12\end{array}$ & $\begin{array}{r}890 \pm 386 \\
2.5 \pm 0.5^{*} \\
0 \cdot 79 \pm 0 \cdot 13\end{array}$ & $\begin{aligned} 725 & \pm 415 \\
2 \cdot 8 & \pm 0 \cdot 9^{* *} \\
0 \cdot 78 & \pm 0 \cdot 11\end{aligned}$ \\
\hline & \multicolumn{5}{|c|}{ Low density lipoprotein cholesterol } \\
\hline Range (mmol/l) & $1 \cdot 45-3.06$ & $3 \cdot 11-3 \cdot 60$ & $3 \cdot 64-4 \cdot 11$ & $4 \cdot 16-5 \cdot 01$ & $5 \cdot 05-7 \cdot 55$ \\
\hline \multirow[t]{2}{*}{$\begin{array}{l}\beta \text { carotene }(\mathrm{nmol} / \mathrm{l}) \\
\text { Retinol ( } \mu \mathrm{mol} / \mathrm{l}) \\
\text { Retinol : retinol binding protein molar ratio }\end{array}$} & $\begin{array}{c}674 \pm 326 \\
2 \cdot 2 \pm 0 \cdot 7 \\
0 \cdot 75 \pm 0 \cdot 13\end{array}$ & $\begin{array}{c}849 \pm 425^{*} \\
2 \cdot 3 \pm 0 \cdot 5 \\
0 \cdot 76 \pm 0 \cdot 11\end{array}$ & $\begin{aligned} 831 & \pm 451 \\
2 \cdot 6 & \pm 0 \cdot 6 * \\
0 \cdot 79 & \pm 0 \cdot 13\end{aligned}$ & $\begin{array}{l}998 \pm 469^{* *} \\
2 \cdot 7 \pm 0 \cdot 9^{* *} \\
0 \cdot 78 \pm 0 \cdot 08\end{array}$ & $\begin{array}{l}976 \pm 460^{* *} \\
2 \cdot 6 \pm 0 \cdot 6^{*} \\
0 \cdot 76 \pm 0 \cdot 12\end{array}$ \\
\hline & \multicolumn{5}{|c|}{ High density lipoprotein cholesterol } \\
\hline Range (mmol/l) & $0 \cdot 87-1 \cdot 33$ & $1 \cdot 34-1 \cdot 47$ & $1.48-1.66$ & $1 \cdot 67-1.79$ & $1 \cdot 80-2 \cdot 55$ \\
\hline $\begin{array}{l}\beta \text { carotene }(\mathrm{nmol} / \mathrm{l}) \\
\text { Retinol ( } \mu \mathrm{mol} / \mathrm{l}) \\
\text { Retinol : retinol binding protein molar ratio }\end{array}$ & $\begin{array}{c}713 \pm 419 \\
2 \cdot 5 \pm 0 \cdot 6 \\
0 \cdot 78 \pm 0 \cdot 10\end{array}$ & $\begin{array}{l}721 \pm 305 \\
2 \cdot 5 \pm 0 \cdot 8 \\
0 \cdot 74 \pm 0 \cdot 13\end{array}$ & $\begin{array}{l}946 \pm 454^{*} \\
2.5 \pm 0.6 \\
0.78 \pm 0.07\end{array}$ & $\begin{array}{c}931 \pm 402 * \\
2 \cdot 5 \pm 0 \cdot 8 \\
0 \cdot 77 \pm 0 \cdot 13\end{array}$ & $\begin{array}{c}1023 \pm 548^{* *} \\
2 \cdot 5 \pm 0 \cdot 6 \\
0 \cdot 79 \pm 0 \cdot 13\end{array}$ \\
\hline
\end{tabular}

Conversion: SI to traditional units-Cholesterol: $1 \mathrm{mmol} / 1 \approx 38.7 \mathrm{mg} / 100 \mathrm{ml}$. $\beta$ carotene: $1 \mathrm{nmol} / 1 \approx 53.7 \mathrm{ng} / 100 \mathrm{ml}$. Retinol: $1 \mu \mathrm{mol} / 1 \approx$ $28.6 \mu \mathrm{g} / 100 \mathrm{ml}$.
${ }^{*} \mathrm{p}<0.05,{ }^{*} \mathrm{p}<0.01,{ }^{* * *} \mathrm{p}<0.001$ compared with quintile $\mathrm{I}$.

cholesterol and phospholipid contents in mononuclear cells, and measured retinoid concentrations. The in vitro effects of lipoprotein concentration on plasma membranes of fibroblasts and mononuclear cells were also studied.

\section{Subjects and methods}

We screened 300 healthy male employees of the Greater London Council aged $25-55$ by measuring total serum cholesterol concentration. On the basis of the cholesterol concentration adjusted for age we recalled 150 subjects representing the top and bottom quintiles and modal decile. None of the recalled subjects had xanthomas or xanthe- protein cholesterol concentrations were estimated by difference. 0

Blood mononuclear cells (comprising $>90 \%$ lymphocytes) were isolated using Ficoll-Hypaque of density $1.077 \mathrm{~g} / \mathrm{ml} .{ }^{14}$ Fluidity was measured by fluorescence depolarisation of 1,6 diphenyl 1,3,5hexatriene as the relative microviscosity, with which it is inversely related, using an Elscint microviscometer after incubation of the cells with 1,6 diphenyl 1,3,5-hexatriene. ${ }^{15}$ The cell pellet was solubilised in $0.5 \mathrm{~mol}(20 \mathrm{~g})$ sodium hydroxide $/ 1$ and extracted with chloroform; unesterified cholesterol was measured enzymatically (Boehringer Mannheim catalogue No 13905) and phospholipid content colometrically after perchloric acid digestion. ${ }^{16}$

Concentrations of $\beta$ carotene and retinol were measured after extraction of whole serum with a mixture of isopropanol and toluene by high pressure liquid chromatography on a Micropak MCH-10 
reverse phase column using retinol acetate as the internal standard. Retinol binding protein was measured by radial immunodiffusion using Behring LC Partigen plates.

For studies in vitro blood mononuclear cells were incubated for 72 hours in medium containing $10 \%$ lipoprotein deficient serum ${ }^{14}$ with added low density lipoprotein at concentrations of lipoprotein cholesterol from 0 to $2.6 \mathrm{mmol} / 1$ (0 to $101 \mathrm{mg} / 100 \mathrm{ml})$. Human fibroblasts derived from fetal lung were cultured to confluence; cells were incubated for 24 hours in lipoprotein deficient serum containing low density lipoprotein at cholesterol concentrations from 0 to $0.65 \mathrm{mmol} / 1(0$ to $25 \mathrm{mg} / 100 \mathrm{ml}$ ). Measurements of microviscosity and assays of cellular unesterified cholesterol and phospholipid concentrations were performed as above. Protein was measured by the method of Lowry. ${ }^{17}$ The molar ratio of cholesterol to phospholipid was recorded as well as cellular cholesterol content because the ratio is a more sensitive index of membrane cholesterol concentration and is an important determinant of fluidity.

\section{Results}

\section{POPULATION STUDY}

Regression to the mean in the second sampling resulted in some redistribution of serum cholesterol concentrations; results relate to the serum cholesterol and lipoprotein concentrations in the second samples. Table I shows the findings in the population study. The molar ratio of unesterified cholesterol to phospholipid in mononuclear cells showed a trend to a direct relation with total serum cholesterol concentration, which was attributable to a positive association with increasing very low density lipoprotein cholesterol concentration; these trends, however, were not significant. There was no relationship between low or high density lipoprotein cholesterol concentrations (the major components of total serum cholesterol) and the cellular ratio of cholesterol to phospholipid. Relative microviscosity of the mononuclear cells showed no relation with low or high density lipoprotein cholesterol concentrations but a weak negative correlation with very low density lipoprotein concentrations $(r=-0.164, p<0.05)$

Table II shows retinol and $\beta$ carotene concentrations related to cholesterol concentrations in serum and in the lipoprotein classes. Concentrations of $\beta$ carotene and retinol increased with increasing concentrations of plasma cholesterol; this reflects in the case of $\beta$ carotene direct relations with both low $(r=0.26, p<0.01)$ and high density lipoprotein cholesterol concentrations $(r=0.25, p<0.01)$; and in the case of retinol a positive correlation with low $(r=0.27, p<$ $0.001)$ and very low density lipoprotein cholesterol concentrations $(\mathrm{r}=0.34, \mathrm{p}<0.001)$. The degree of saturation of its binding protein by retinol was unrelated to lipoprotein concentration.

Table III shows that the familiar increase in cholesterol and low density lipoprotein cholesterol concentrations with age is associated with a similar trend in $\beta$ carotene concentration.

TABLE III-Age trends in serum cholesterol, lipoprotein, and retinoid concentrations

\begin{tabular}{|c|c|c|c|}
\hline Age (years): & $26-35$ & $36-45$ & $46-55$ \\
\hline $\begin{array}{l}\text { Total cholesterol }(\mathrm{mmol} / \mathrm{l}) \\
\text { Very low density lipoproteir }\end{array}$ & $5 \cdot 8 \div 1 \cdot 2$ & $6 \cdot 2 \div 1 \cdot 6$ & $6 \cdot 5+1 \cdot 4$ \\
\hline $\begin{array}{l}\text { Very low density lipoprotein } \\
\text { cholesterol (mmol/1) } \\
\text { Low density lipoprotein cholesterol }\end{array}$ & $0.47 \div 0.44$ & $0.53 \div 0.49$ & $0.57 \pm 0.42$ \\
\hline & $3 \cdot 7: 1 \cdot 0$ & $4 \cdot 2 \pm 1 \cdot 3$ & $4 \cdot 4 \pm 1 \cdot 3 *$ \\
\hline $\begin{array}{l}(\mathrm{mmol} / \mathrm{l}) \\
\text { P carotene }(\mathrm{nmol} / \mathrm{l}) \\
\operatorname{Retinol}(\mu \mathrm{mol} / \mathrm{l})\end{array}$ & $\begin{array}{c:c}1 \cdot 6 & 0 \cdot 3 \\
739 & 326 \\
2 \cdot 4 & 0 \cdot 6\end{array}$ & $\begin{array}{c:c}1 \cdot 6 & 0.3 \\
905 & 440 \\
2 \cdot 5 & 0.8\end{array}$ & $\begin{array}{l}1 \cdot 6+0 \cdot 3 \\
948+529^{*} \\
2 \cdot 5+0 \cdot 6\end{array}$ \\
\hline
\end{tabular}

Conversion: SI to traditional units-Cholesterol: $1 \mathrm{mmol} / 1 \approx 38.7 \mathrm{mg} / 100 \mathrm{ml}$. $\beta$ carotene: $1 \mathrm{nmol} / 1 \approx 53.7 \mathrm{ng} / 100 \mathrm{ml}$. Retinol: $1 \mu \mathrm{mol} / 1 \approx 28.6 \mu \mathrm{g} / 100 \mathrm{ml}$. ${ }^{*} \mathrm{p}-0.05$ compared with $26-35$ year age group.

\section{IN VITRO STUDY}

The figure shows the effects on fibroblasts of varying low density lipoprotein cholesterol concentration in the incubation medium in the range $0-0 \cdot 26 \mathrm{mmol} / \mathrm{l}(0-10 \mathrm{mg} / 100 \mathrm{ml})$. Studies on the lipid and lipoprotein concentrations of peripheral lymph have suggested that tissue fluid cholesterol and low density lipoprotein cholesterol concentrations are of the order of one tenth of those in plasma. ${ }^{18}$ There was little variation in relative microviscosity in the range of low density lipoprotein cholesterol $0 \cdot 052-0.26 \mathrm{mmol} / 1(2-10 \mathrm{mg} / 100 \mathrm{ml})$; lower low density lipoprotein cholesterol concentrations were associated with reduced values. The unesterified cholesterol content of cells (related to cell protein) showed a similar trend, as did the ratio of cholesterol to phospholipid. The ratio was strongly correlated with relative microviscosity $(r=0.74, p<0.05)$.

Lymphocytes incubated in the presence of the same range of low density lipoprotein cholesterol concentrations also showed a plateau in their relative microviscosity and ratio of cholesterol to phospholipid at concentrations between 0.052 and $0.26 \mathrm{mmol} / 1$ ( 2 and 10 $\mathrm{mg} / 100 \mathrm{ml})$.
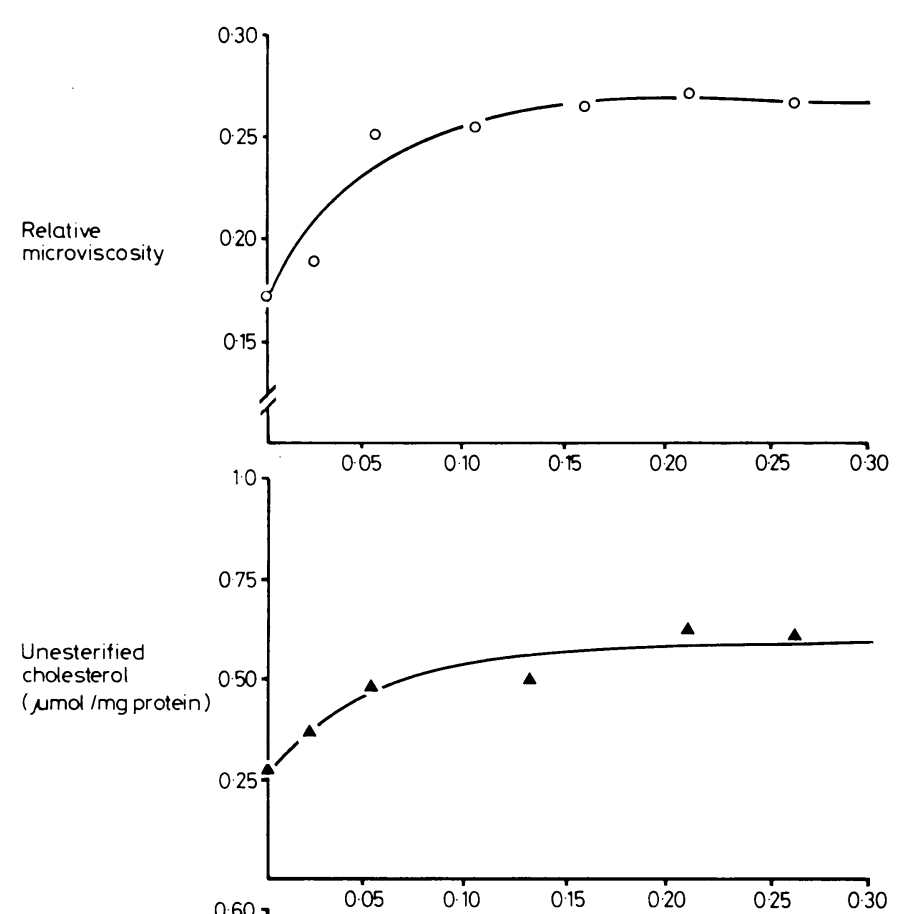

Cholesterol phospholipid molar ratio

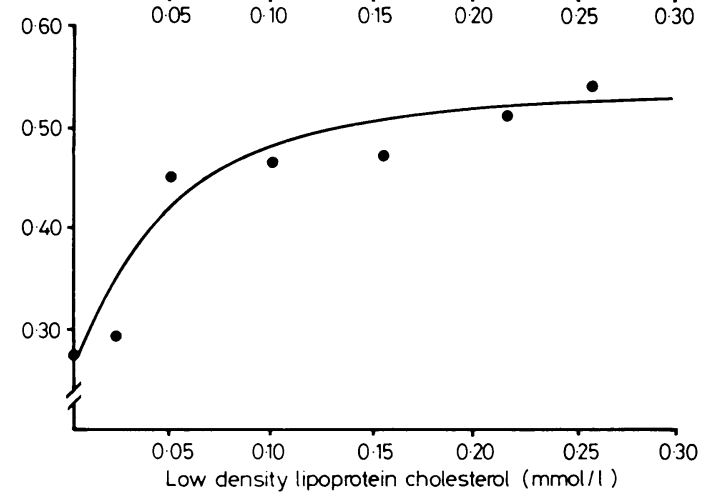

Relative microviscosity, cholesterol to phospholipid molar ratio, and cholesterol content of fibroblasts incubated for 24 hours in medium containing human lipoprotein deficient serum supplemented with increasing concentrations of low density lipoprotein cholesterol.

Conversion: SI to traditional units-Cholesterol: $1 \mathrm{mmol} / 1 \approx 38 \cdot 7 \mathrm{mg} / 100 \mathrm{ml}$

\section{Discussion}

It has been hypothesised that reducing plasma cholesterol $\underset{\sigma}{\sigma}$ concentration by drugs or diet might "lead to pathological 0 processes" as a consequence of a resulting low cholesterol content in cells, leading to increased fluidity of the plasma membrane. ${ }^{6} \stackrel{\text { ? }}{\rightarrow}$ This implies a causal role for low cholesterol concentrations in $T$ the aetiology of non-cardiovascular disease; hence it was important to examine the extent to which the cholesterol concentration in body fluids influences the lipid content and physical properties of plasma membranes. We made observations on blood mononuclear cells from normal men with a wide range of serum cholesterol concentrations and ages. To extend the study to still lower lipid concentrations and to examine cells other than blood mononuclear cells we studied the membrane fluidity and 
composition of fibroblasts as well as mononuclear cells incubated for 24-72 hours in a range of low density lipoprotein cholesterol concentrations from zero to those typical of tissue fluid.

It was evident that the fluidity of mononuclear cell plasma membranes is constant over the extensive range of plasma cholesterol concentrations seen in the normal population (group means $4 \cdot 43-8 \cdot 22 \mathrm{mmol} / 1(171-318 \mathrm{mg} / 100 \mathrm{ml})$ ), reflecting a range of low density lipoprotein cholesterol concentrations from 1.45 to $7.55 \mathrm{mmol} / \mathrm{l}(56$ to $292 \mathrm{mg} / 100 \mathrm{ml}$ ). In the in vitro study the fluidity of both mononuclear cell and fibroblast membranes was little affected by differences in the low density lipoprotein cholesterol content of the incubation medium in the range $0 \cdot 05-0.26 \mathrm{mmol} / 1(2-10 \mathrm{mg} / 100 \mathrm{ml})$ but increased substantially at concentrations below $0.05 \mathrm{mmol} / 1$. Available information on tissue fluid and low density lipoprotein cholesterol concentrations suggests that they are about one tenth of those in plasma, ${ }^{18}$ and hence the concentrations in plasma corresponding to $0.05-0.26 \mathrm{mmol} / 1$ in tissue fluid are of the order of $0 \cdot 5-2 \cdot 6$ $\mathrm{mmol} / 1(19-101 \mathrm{mg} / 100 \mathrm{ml})$. The fifth percentile of plasma low density lipoprotein cholesterol concentration observed in this study and in a normal British population ${ }^{19}$ was $2.6 \mathrm{mmol} / 1$ (101 $\mathrm{mg} / 100 \mathrm{ml})$ and the first percentile was $1.75 \mathrm{mmol} / 1(68 \mathrm{mg} / 100$ $\mathrm{ml})$. The corresponding fifth percentiles for total plasma cholesterol concentration were 4.05 and $4.5 \mathrm{mmol} / 1$ respectively $(157$ and $174 \mathrm{mg} / 100 \mathrm{ml})$. Similar trends were noted in cell content of unesterified cholesterol, as previously noted in mononuclear cells,,$^{20}$ and in the ratio of cholesterol to phospholipid, which is a major determinant of fluidity.

Thus cell membrane fluidity is unaffected by a wide range of low density lipoprotein cholesterol concentrations, except at concentrations considerably lower than those corresponding to the first percentile in normal subjects.

Most cells, including blood mononuclear cells, fibroblasts, and adrenal cortical cells but not tissue macrophages, possess high affinity receptors for low density lipoprotein that mediate uptake of this lipoprotein even at low concentrations. ${ }^{21}$ Regulation of the activity of this receptor is one of the important homeostatic mechanisms controlling cellular unesterified cholesterol content. ${ }^{20}$ If uptake of cholesterol becomes less as the low density lipoprotein concentration decreases, in situ synthesis of cholesterol increases due to derepression of the rate limiting enzyme for this pathway. ${ }^{21}$ Hence the stability of plasma membrane fluidity observed in this study, and of the unesterified cholesterol concentration that it largely reflects, is by no means surprising; and probably this property is common to all cells possessing the low density lipoprotein receptor pathway. The choice of mononuclear cells in the present investigation was based on their accessibility in a population study in quantities permitting measurements in the freshly isolated state. Such cells recirculate between lymphoid organs and the blood ${ }^{22}$ and are exposed to tissue fluid concentrations of low density lipoprotein for most of their life span. Fibroblasts were selected as an example of a solid tissue cell continuously exposed to the low tissue fluid concentrations of this lipoprotein.

Kark et $a^{13}$ showed a correlation between serum retinol and cholesterol concentrations, which reflects a relation of serum retinol with low density lipoprotein cholesterol concentrations. ${ }^{2:}$ Their studies were performed on stored sera. Using fresh sera we confirmed these observations and in addition showed associations of retinol with very low density lipoprotein cholesterol and of $\beta$ carotene with low and high density lipoprotein cholesterol. The mechanisms underlying the relation between retinol and lipid transport are unclear; dietary vitamin A (converted to retinyl esters in the intestine) is transported in chylomicrons in association with dietary fats and cholesterol. Subsequent transport of retinol does not involve lipoproteins ${ }^{24}$; it is in the form of a retinol-retinol binding protein-prealbumin complex. We found no relation between the degree of saturation of the binding protein by retinol and serum or lipoprotein cholesterol concentrations. By contrast, 3 carotene is transported with lipids in plasma lipoproteins, and hence the associations observed are predictable. These findings lend support to the view that a relation between cholesterol concentrations and cancer may be secondary to an association between retinol concentration and the incidence of cancer. ${ }^{13}$

There were no differences in the fluidity of plasma membranes or cellular cholesterol content between subjects with serum cholesterol concentrations in the lowest quintile compared with those in the highest. Our studies in vitro show no substantial change in these measurements until the external low density lipoprotein cholesterol concentration is reduced to less than $0.05 \mathrm{mmol} / 1(2 \mathrm{mg} / 100 \mathrm{ml})$; this probably corresponds to a serum low density lipoprotein cholesterol concentration of 0.5 $\mathrm{mmol} / \mathrm{l}(19 \mathrm{mg} / 100 \mathrm{ml})$, which is below the first percentile $(2 \cdot 0$ $\mathrm{mmol} / 1(77 \mathrm{mg} / 100 \mathrm{ml})$ and $1.75 \mathrm{mmol} / \mathrm{l}(68 \mathrm{mg} / 100 \mathrm{ml}))$ in a British population sample ${ }^{19}$ and in this study respectively. Hence we found no evidence of deleterious effects on the cell at serum concentrations of cholesterol attainable by diet or drug treatment of hyperlipidaemia or seen in any but a minute fraction of the normal population.

\section{References}

1 World Health Organisation Expert Committee. Prevention of coronary heart disease WHO Tech Rep Ser 1982; No 678:1-53.

Wynder EL, Blackburn H, Lewis B, Wissler RW. Conference on the health effects of blood lipids: optimal distributions for populations. Prev Med $1979 ; 8: 609-732$.

${ }^{3}$ Williams RR, Sorlie PD, Feinleib M. McNamara PM, Kannel WB, Dawber TR. Cancer incidence by levels of cholesterol. FAMA $1981 ; \mathbf{2 4 5}$ : 247-52.

4 Committee of Principal Investigators. Report of a WHO cooperative trial on primary prevention of ischaemic heart disease using clofibrate to lower serum cholesterol mortality: follow up. Lancet 1980 ;ii :379-84.

Coronary Drug Project Research Group. Clofibrate and niacin in coronary heart disease. FAMA 1975;231:360-81.

${ }^{6}$ Oliver MF. Serum cholesterol-the knave of hearts and the joker. Lancet $1981 ;$ ii :1090-5.

Inbar M, Shinitzky M. Cholesterol as a bioregulator in the development and inhibition of leukemia. Proc Natl Acad Sci US A 1974;71:4229-34.

"Peel WE, Thomson AER. Cholesterol content and fluidity of normal human and chronic lymphocytic leukemia lymphocytes in relation to serum cholesterol level. Leuk Res 1980;4:601-10.

Rose G, Shipley MJ. Plasma lipids and mortality: a source of error. Lancet $1980 ; \mathrm{i}: 523-6$.

11 International Collaborative Group. Circulating cholesterol level and risk of death from cancer in men aged 40 to 69 years. $\mathcal{F} A M A 1982 ; \mathbf{2 4 8}$ : 2853-9.

${ }^{11}$ Wald N, Idle M, Boreham J, Bailey A. Low serum vitamin-A and subsequent risk of cancer. Lancet $1980 ;$ ii:813-5.

12. Shekelle RB, Lepper M, Liu S, et al. Dietary vitamin A and risk of cancer in the Western Electric Study. Lancet 1981;ii:1185-90.

${ }^{13}$ Kark JD, Smith AH, Hames CG. Serum retinol and the inverse relationship between serum cholesterol and cancer. $\mathrm{Br}$ Med $\mathcal{F} 1982 ; \mathbf{2 8 4}: 152-4$

${ }_{14}$ Mistry P, Miller NE, Laker MR, Hazzard WR, Lewis B. Individual varia tion in the effects of dietary cholesterol on plasma lipoproteins and cellular cholesterol homeostasis in man. Studies of low density lipoprotein receptor activity and 3-hydroxy-3 methylglutaryl coenzyme A reductase in blood mononuclear cells. $\mathcal{F}$ Clin Invest $1981 ; 67: 493-502$.

1. Shinitzky $M$, Inbar $M$. Differences in microviscosity induced by different cholesterol levels in the surface membrane lipid layer of normal lymphocytes and malignant lymphoma cells. $f$ Mol Biol 1974 ;85:603-15.

${ }^{16}$ Bartlett GR. Phosphorus assay in column chromatography. $\mathcal{F}$ Biol Chem $1959 ; 234: 466-8$.

17 Lowry OH, Rosebrough NJ, Farr AL, Randall RJ. Protein measurement with the folin phenol reagent. F Biol Chem 1951;193:265-75.

is Reichl D, Myant NB, Brown MS, Goldstein JL. Biologically active low density lipoprotein in human peripheral lymph. $\mathcal{f}$ Clin Invest 1978;61 64-71.

19 Lewis B, Chait A, Wootton IDP, et al. Frequency of risk factors for ischaemic heart disease in a healthy British population with particular reference to serum lipoprotein levels. Lancet 1974 ; i:141-6.

2 "Brown MS, Faust JR, Goldstein JL. Role of the low density lipoprotein receptor in regulating the content of free and esterified cholesterol in human fibroblasts. 7 Clin Invest $1975 ; \mathbf{5 5}: 783-93$.

Goldstein JL, Brown MS. The low density lipoprotein pathway and its relation to atherosclerosis. Annu Rev Biochem 1977;46:897-930.

$\because 2$ Ford WL. Lymphocyte migration and immune responses. In: Kallos P, Waksman BH, de Weck A, eds. Progress in Allergy 19. Basle: Karger, $1975: 1-59$.

Smith AH, Hoggard BM. Retinol, carotene and the cancer/cholesterol association. Lancet $1981 ;$ i:1371-2.

$\because$ Smith JE, Goodman DS. Retinol-binding protein and the regulation of vitamin A transport. Fed Proc 1979;38:2504-9.

(Accepted 22 March 1983)

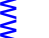
. . 